\title{
Plants growing in abandoned mines of Portugal are useful for biogeochemical exploration of arsenic, antimony, tungsten and mine reclamation
}

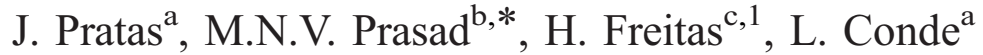 \\ ${ }^{a}$ Departamento de Ciências da Terra, Faculdade de Ciências e Tecnologia da Universidade de Coimbra. 3000 Coimbra, Portugal \\ ${ }^{\mathrm{b}}$ Department of Plant Sciences, University of Hyderabad, Hyderabad 500046, A.P. India \\ ${ }^{\mathrm{c}}$ Departamento de Botânica, Faculdade de Ciências e Tecnologia da Universidade de Coimbra. 3000 Coimbra, Portugal
}

Received 14 January 2004; accepted 9 November 2004

Available online 19 December 2004

\begin{abstract}
Several plants across taxonomic hierarchy have evolved heavy metal tolerance strategies and detoxification mechanisms that enable them to survive, grow and reproduce in metal contaminated and polluted sites. Plants growing on the abandoned Portuguese mines, highly contaminated with arsenic (As), antimony ( $\mathrm{Sb}$ ) and tungsten (W), have been studied for their biogeochemical prospecting and mine stabilization potential. The results of soil analysis show relevant anomalies of As, Sb and W. We have observed that the plant species accumulating tungsten are Digitalis purpurea, Chamaespartium tridentatum, Cistus ladanifer, Pinus pinaster, Erica umbellata, and Quercus ilex subsp. ballota. Accumulators of antimony are D. purpurea, E. umbellata, Calluna vulgaris and C. ladanifer. Accumulations of arsenic are found in the old needles of P. pinaster, Calluna vulgaris and C. tridentatum and leaves of C. ladanifer, E. umbellate and Q. ilex subsp. ballota. These are the key stone species allowing biogeochemical delineation of areas of anomalous soil composition.
\end{abstract}

(C) 2004 Elsevier B.V. All rights reserved.

Keywords: Arsenic; Antimony; Tungsten; Abandoned mines; Portugal; Biogeochemical prospecting; Phytostabilization

\section{Introduction}

The use of plant species as indicators of metal contamination (natural and/or anthropogenic) is based on their response to the elements present in the

\footnotetext{
* Corresponding author.

E-mail addresses: mnvsl@uohyd.ernet.in (M.N.V. Prasad), hfreitas@ci.uc.pt (H. Freitas).

${ }^{1}$ Tel.: +351 239 855215; fax: +351239855211.
}

substrate (Kabata-Pendias, 2001). Plants growing on abandoned mine sites usually indicate the mineral composition of the soil. These plant species are tolerant to metals, and they are able to accumulate or exclude toxic metals. Thus, trace-metal-accumulating plants are of immense use for biogeochemical prospecting and geochemical exploration (Badri and Springuel, 1994; Brooks, 1983; McInnes et al., 1996). Therefore, metal-tolerant perennials and plants with 
high biomass and bioproductivity are useful in phytostabilization and mine restoration (Hooper and Vitousek, 1997). Mining activities leave behind vast amount of mine spoils and mine tailings, which will become the sources of metal contamination and pollution in the environment. The direct effects of these processes will be the degradation of cultivated, forest or grazing land with concomitant reduction in production (Wong, 2003). The indirect effects of mining activities are air, soil and water pollution and siltation of rivers. Both the direct and indirect effects would eventually harm biodiversity and economic wealth (Bradshaw, 1993). Plant communities that are tolerant to imposed stress conditions can fulfil the objectives of stabilization, pollution control, visual improvement and removal of threats to mankind. The constraints related to plant establishment and amendment of the physical and chemical properties of the toxic metalliferous soils depend upon the choice of appropriate plant species that will be able to grow in such a hostile environment. Thus, the plant community tolerant to toxic trace elements play a major role in remediation of degraded mine soils. Plants tolerant to toxic levels of trace elements respond by exclusion, indication or accumulation of metals (Baker, 1981). Thus, more information about plant communities that are growing on metal-contaminated soils is essential to determine their application for mine stabilization/ remediation and biogeochemical exploration (Baker et al., 1994; Badri and Springuel, 1994; Brooks, 1983; Fletcher, 1981; Levinson, 1974; Kovalevskii, 1979; McInnes et al., 1996).

\section{Area description, methods and material studied}

This study is one of the parts of the continuing investigations on the biogeochemical prospecting and mine stabilization/remediation to evaluate the potential of plant species and communities established on abandoned mines (Freitas et al., 2004a,b). The study area includes two abandoned mines, viz., Gatas and Santa mine that form the denominated Sarzedas mine. The area investigated is situated close to the Sarzedas village $39^{\circ} 52^{\prime} 30^{\prime \prime} \mathrm{N} ; 7^{\circ} 32^{\prime} 20^{\prime \prime} \mathrm{W}$ (Castelo Branco county, central Portugal). The Sarzedas mineralizations are emplaced in quartzous veins striking $\mathrm{N} 60^{\circ} \mathrm{E}$ (Santa mine) and $\mathrm{N} 20^{\circ} \mathrm{W}$ (Gatas mine), filling late
Hercynian fractures, which cut the "Schist-Graywacke Complex." The acid rock veins cutting the complex are frequent, and these are identical to ante-Ordovician veins appearing in the area. These veins show indication of hydrothermal alteration, and they are mineralized by disseminated sulphides. The main mineralization is of the vein type, and it is made of wolframite (ferberite), stibnite, pyrite, arsenopyrite and, seldom, by chalcopyrite, sphalerite and galena. Gold occurs in its native form. Soils are barely developed, and they are mainly mountain soils, especially cambisoils and lithosoils. In one of these sites, they are almost entirely made of tailing debris. In the study area, two transects were made on the mineralized zone and in the tailings. On these transects, soils and plants were collected in a 2-m circle every $40 \mathrm{~m}$, ensuring that about $1 / 3$ of the total samples were in the selected contaminated areas. Two transverse profiles within the mineralized area and tailings were chosen as sites for collection of materials. In these profiles, soils were collected at intervals of 40 $\mathrm{m}$. Soil samples were always collected from the B horizon (not always at the same depth due to the presence of mountain soils with variable and limited thickness) to minimize the influence of the organic matter present in superficial horizons. Each soil sample consisted of a homogenate of four subsample points located in an imaginary circle about $2 \mathrm{~m}$ around the sampling point. The soil samples were dried at 80 ${ }^{\circ} \mathrm{C}$ and passed through a 100 -mesh sieve. Plants were collected within the same zone and later identified following the local herbarium and floras (Franco, 1971, 1984). The first step of sample preparation included separation of samples into several subsamples based on organs collected and growing ages. Plant samples were cleaned with fresh-water, rinsed with deionized water and air-dried at room temperature for several days. The air-dried plant samples were powdered homogenously and digested for elemental analysis (Kovalevskii, 1979; Brooks, 1983; Pereira et al., 2003). Analytical methods included colorimetry for W (Quin and Brooks, 1972), atomic absorption spectrophotometry (Perkin-Elmer, 2380) for Ag, Co, $\mathrm{Cr}, \mathrm{Cu}, \mathrm{Fe}, \mathrm{Mn}, \mathrm{Ni}, \mathrm{Pb}$ and $\mathrm{Zn}$ and hydride generation for As and Sb (Van Loon, 1985; Vijan et al., 1976).

To determine plant's ability to accumulate heavy metals and to use plants to detect metalliferous rocks, the Index of Biogeochemical Anomaly (IBA) was 
Table 1

Soil data for different trace elements at the study site $\left(\mathrm{mg} \mathrm{kg}^{-1}\right)$

\begin{tabular}{lcccc}
\hline$N=24$ & Range & Mean & Median & Standard deviation \\
\hline $\mathrm{PH}$ & $3.3-5.2$ & 4.7 & 4.8 & 0.5 \\
$\mathrm{Ag}$ & $0.69-1.91$ & 0.98 & 0.92 & 0.32 \\
$\mathrm{As}$ & $11.1-651.1$ & 76.3 & 19.9 & 181.5 \\
$\mathrm{Co}$ & $5.4-14.9$ & 8.8 & 8.41 & 2.6 \\
$\mathrm{Cr}$ & $50.7-129.1$ & 96.5 & 100.2 & 26.3 \\
$\mathrm{Cu}$ & $15.5-78.2$ & 40.7 & 35.1 & 21.1 \\
$\mathrm{Fe}$ & $21881-58644$ & 39981 & 37356 & 12883 \\
$\mathrm{Mn}$ & $22-92$ & 50 & 47 & 22 \\
$\mathrm{Ni}$ & $11.2-52.5$ & 21.8 & 19.7 & 10.2 \\
$\mathrm{~Pb}$ & $35.7-416.7$ & 85.4 & 53.9 & 105.9 \\
$\mathrm{Sb}$ & $30.5-5986.4$ & 663.1 & 87.8 & 1689.1 \\
$\mathrm{~W}$ & $0.8-684.0$ & 663.1 & 2.9 & 52.3 \\
$\mathrm{Zn}$ & $29-126.6$ & 58.8 & 53.3 & 24.3 \\
\hline
\end{tabular}

applied. This index is calculated based on metals concentration in soils and plant tissues, and it is based on principal component analysis (PCA). The index allows plant selection (including their parts) that would indicate better ore deposits. This selection permits the organization of a hierarchy of metal-tolerant species that can be used in biogeochemical prospecting. To obtain an index that can be considered responsible for the origin of the anomaly in plant material as a result of the soil, a Biogeochemical Indicator Index (BII) was estimated. It corresponds to the ratio between the absolute values of the biogeochemical and pedogeochemical anomaly (Pratas, 1996).

Statistical analysis involved correlation analysis and PCA. The aim of PCA is to reduce the dimensionality while preserving the variance-covariance structure. The analysis starts with $p$ random variables $X_{1}, X_{2}, \ldots$, $X_{p}$ where no assumption of multivariate normality is required. If the principal components are derived from multivariate normal random variables, then they have an interesting geometric property. The axes of the constant density ellipsoids correspond to the principal components (Fletcher, 1981; Pereira et al., 2003; Singh et al., 1994; C.V.R.M., 1988).

In this first step, individuals were all taken as principal elements, and the main variables were those related to the elements that we knew to be present in the paragenesis of the mineralization, thereby confirming which secondary elements were associated to the anomaly and to which samples. This procedure helped us to verify which samples promote the origin of the anomalies caused by the mineralization, and that will be important in the subsequent procedure.

In the second step of the analysis, the results obtained for each plant species and respective soil were handled together, taking into consideration that, for each area, the principal elements in the factorial axis were those responsible for the soil contamination. Following on this approach, we arrived at the concentrations of trace elements in plant tissues that showed significant soil anomalies.

\section{Results}

The summary of soil trace element data is shown in Table 1. The total data of soils are object of analysis by PCA. The result of the two principal axes that explained more that $75 \%$ of the total data are shown in Fig. 1. This result shows that, from the elements present in the soils, $\mathrm{Ag}, \mathrm{As}, \mathrm{Pb}, \mathrm{Sb}$ and $\mathrm{W}$ are those that show the most relevant anomalies. The $\mathrm{pH}$ shows a negative correlation to the mineralization. Low $\mathrm{pH}$ values observed in the vicinity of the mineralized area

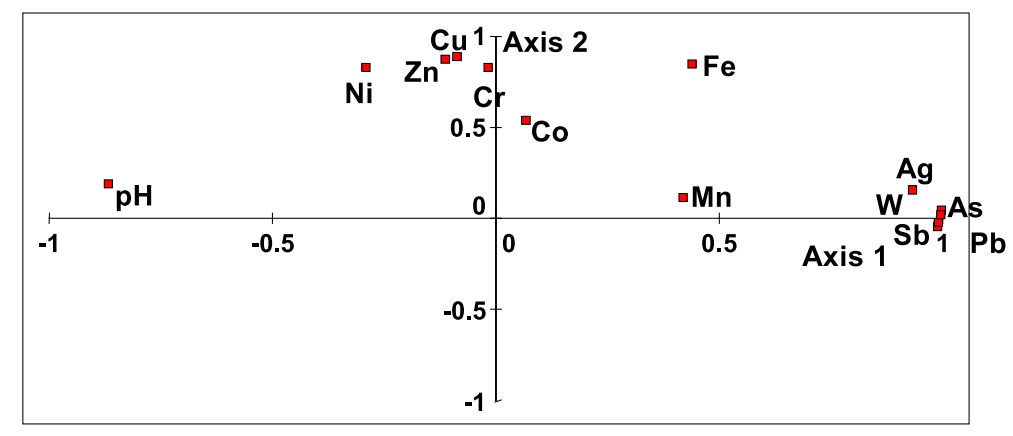

Fig. 1. Projection of the elements in the two first Axes of the PCA. 
Table 2

Composition of As, $\mathrm{Sb}$ and $\mathrm{W}$ in plant samples (twigs, unless otherwise mentioned) collected from the abandoned mines of Portugal

\begin{tabular}{|c|c|c|c|c|c|c|c|c|c|c|}
\hline \multirow[t]{2}{*}{ Family and Plant } & \multirow[t]{2}{*}{ No. of samples } & \multicolumn{3}{|l|}{ As } & \multicolumn{3}{|l|}{$\mathrm{Sb}$} & \multicolumn{3}{|l|}{ W } \\
\hline & & Min & Max & $T / t$ & Min & Max & $T / t$ & Min & Max & $T / t$ \\
\hline \multicolumn{11}{|l|}{ Pinaceae } \\
\hline Pinus pinaster Aiton-needle (new) & 22 & 0.12 & 9.99 & 45.4 & 0.01 & 1.41 & 26.6 & 0.06 & 2.65 & 18.9 \\
\hline Needle (old) & 22 & 0.11 & 30.07 & 136.7 & 0.01 & 1.85 & 29.0 & 0.05 & 10.7 & 118.9 \\
\hline Twig (new) & 22 & 0.08 & 0.34 & 2.8 & 0.01 & 1.89 & 29.0 & 0.05 & 3.81 & 42.3 \\
\hline Twig (old) & 22 & 0.08 & 0.32 & 2.7 & 0.01 & 0.17 & 11.6 & 0.03 & 2.48 & 31.0 \\
\hline \multicolumn{11}{|l|}{ Fabaceae } \\
\hline Chamaespartinum tridentatum (L.) P. Gibbs & 23 & 0.09 & 0.54 & 3.9 & 0.01 & 0.42 & 16.3 & 0.03 & 5.74 & 47.8 \\
\hline Genista triacanthos Brot. & 6 & 0.15 & 0.18 & 1.1 & 0.03 & 0.09 & 1.4 & 0.12 & 1.03 & 8.6 \\
\hline \multicolumn{11}{|l|}{ Ericaceae } \\
\hline Calluna vulgaris (L.) Hull. & 22 & 0.10 & 0.62 & 3.3 & 0.04 & 1.25 & 20.8 & 0.18 & 9.74 & 36.6 \\
\hline Erica umbellata $\mathrm{L}$. & 17 & 0.11 & 0.64 & 3.9 & 0.05 & 1.74 & 27.0 & 0.08 & 4.04 & 28.5 \\
\hline \multicolumn{11}{|l|}{ Fagaceae } \\
\hline Quercus ilex L. subsp. ballota (Desf.) Samp.-leaves & 11 & 0.32 & 3.6 & 8.6 & 0.04 & 2.07 & 20.1 & 0.20 & 4.07 & 20.8 \\
\hline Twigs & 11 & 0.18 & 1.57 & 5.4 & 0.03 & 0.47 & 10.3 & 0.05 & 2.71 & 56.3 \\
\hline Q. suber L.-leaves & 7 & 0.15 & 1.44 & 6.6 & 0.03 & 2.24 & 29.6 & 0.12 & 3.38 & 28.4 \\
\hline Twigs & 7 & 0.27 & 2.04 & 6.8 & 0.03 & 0.72 & 11.8 & 0.08 & 2.47 & 25.7 \\
\hline \multicolumn{11}{|l|}{ Asteraceae } \\
\hline Helichrysum stoechas (L.) Moench. & 10 & 0.60 & 1.60 & 1.6 & 0.08 & 1.74 & 15.3 & 0.13 & 8.93 & 38.7 \\
\hline Andryala integrifolia $\mathrm{L}$. & 5 & 0.39 & 0.96 & 2.5 & 0.07 & 1.05 & 14.4 & & & \\
\hline \multicolumn{11}{|l|}{ Scrophulariaceae } \\
\hline Digitalis purpurea L. subsp. purpurea & 6 & 0.66 & 9.67 & 13.6 & 1.76 & 139.9 & 54.0 & 14.3 & 90.8 & 79.3 \\
\hline \multicolumn{11}{|l|}{ Poaceae } \\
\hline Agrostis curtisii Kerguelen & 9 & 0.28 & 0.50 & 1.4 & 0.01 & 0.04 & 2.5 & 0.05 & 0.9 & 6.8 \\
\hline \multicolumn{11}{|l|}{ Cystaceae } \\
\hline Cistus ladanifer L. subsp. ladanifer-leaves & 21 & 0.48 & 2.77 & 3.8 & 0.10 & 3.65 & 10.6 & 0.09 & 30.7 & 30.5 \\
\hline Twigs & 21 & 0.20 & 2.38 & 3.6 & 0.02 & 2.84 & 29.3 & 0.04 & 3.55 & 20.4 \\
\hline Halimium ocymoides (Lam.) Willd. & 16 & 0.34 & 0.65 & 1.4 & 0.02 & 0.06 & 2.0 & 0.14 & 0.3 & 2.0 \\
\hline \multicolumn{11}{|l|}{ Myrtaceae } \\
\hline Eucalyptus globulus Labill-leaves & 6 & 0.08 & 0.3 & 3.0 & 0.02 & 0.18 & 4.9 & 0.07 & 2.73 & 30.3 \\
\hline Twigs & 6 & 0.13 & 0.31 & 1.7 & 0.03 & 0.17 & 5.4 & 0.12 & 3.51 & 27.0 \\
\hline \multicolumn{11}{|l|}{ Lamiaceae } \\
\hline Lavandula stoechas L. subsp. stoechas & 14 & 0.31 & 0.58 & 1.0 & 0.09 & 0.19 & 1.2 & 0.18 & 0.61 & 3.4 \\
\hline \multicolumn{11}{|l|}{ Rosaceae } \\
\hline Rubus ulmifolius Schott & 5 & 0.22 & 0.85 & 3.9 & 0.09 & 0.44 & 4.8 & - & - & - \\
\hline
\end{tabular}

$T / t$, relation between the maximum and background level.

can be explained by the presence of sulphides in the mineralization. High levels of sulphides, in particular pyrite and arsenopyrite that are easily weathered, favour the dissolution of the toxic elements, allowing higher dispersion and bioavailability. The absence of high concentrations of $\mathrm{Mn}$ in the soils can be related to the presence of ferberite $\left(\mathrm{Fe} \mathrm{WO}_{4}\right)$ in the mineralization. 
The trace element composition of different plants and their parts is summarized in Table 2. This table also shows the concentrations of $\mathrm{As}, \mathrm{Sb}$ and $\mathrm{W}$ and the ratio between the maximum and the background concentrations $(T / t)$. This background was assumed as the arithmatical mean of the nonanomalous samples resulting from the PCA. Arsenic is accumulated in aerial tissues of Pinus pinaster and Digitalis purpurea. Therefore, these are the species suited for recognizing the anomaly. Specifically, high accumulation of this element was present in leaves, and it increased in the older tissues. This translocation is a common mechanism in plants to avoid toxicity in young leaves as the metabolic activity is higher. $D$. purpurea also accumulated substantial amount of $\mathrm{Sb}$, indicating its tolerance to this element, although the assimilation occurs at low concentrations in the soil. This fact suggests that the relation between the maximum content and the background is not as significant as total concentration in relation to other species. Species that are capable of accumulating W are D. purpurea, Cistus ladanifer, P. pinaster, Calluna vulgaris and Helichrysum stoechas. The major differences were found for Chamaespartium tridentatum, Quercus ilex subsp. ballota and Eucalyptus globulus. To quantify the relationship with the soil, indices of biogeochemical anomaly were calculated (Fig. 2). With respect to the biogeochemical anomaly, $P$. pinaster is the species that shows better information regarding As, especially the old needles (Pratas et al., in press). All the other species do not show anomalies with high discrepancy. With respect to $\mathrm{Sb}, D$. purpurea offers an excellent indication of a strong anomaly, although $C$. ladanifer and $C$. vulgaris can also be considered as good indicators. Globally, $\mathrm{Sb}$ is easier to detect as a pollutant by plant analysis compared to As. W shows important anomalies in Erica umbellata, C. tridentatum, C. vulgaris, D.

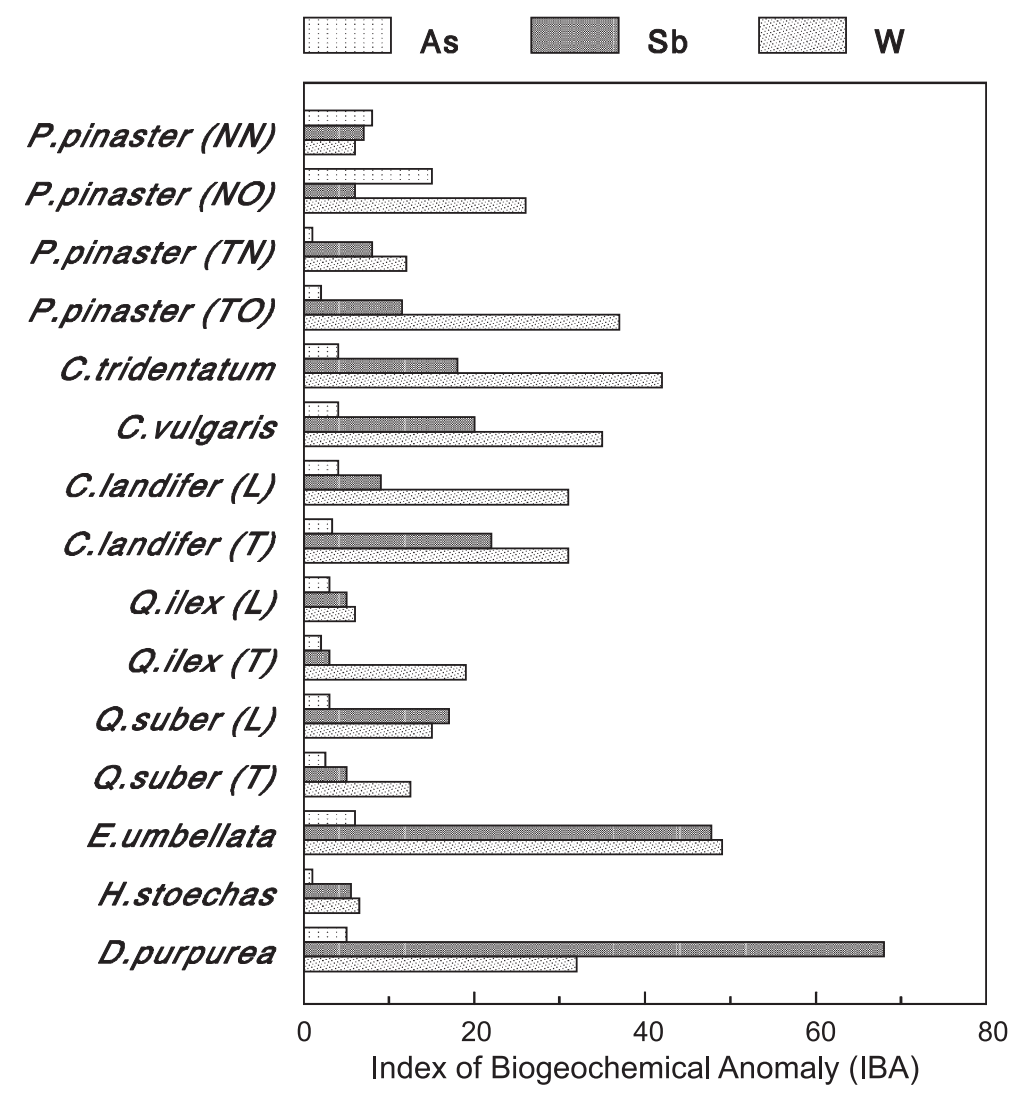

Fig. 2. Index of Biogeochemical Anomaly (IBA). NN—new needles; NO_old needles; TN—new twigs; TO—old twigs; L-leaves; T-twigs. 
purpurea, and $P$. pinaster. In $P$. pinaster, the ideal materials are old tissues, preferably lignified tissues.

Previous analysis took into account the anomaly in plant tissues from the polluted soils, but it did not include a direct relation to the intensity of the anomaly generated by the soils, which is different as the sampled species did not show a uniform distribution in the sampling area. Therefore, the Biogeochemical Indicator Index (BII) was calculated (Fig. 3). Considering the BII, it can be seen that $P$. pinaster easily detects As in these conditions, producing better-defined anomalies than the soils (BII>1). With regard to $\mathrm{Sb}, D$. purpurea, E. umbellata, C. ladanifer and C. vulgaris define pollution. With respect to $\mathrm{W}$, it is observed that the intensity of the anomaly in the soils is higher than in the plants in spite of the good anomalies in the plants. Probably, this is a relative effect only because the low meteorization of the $\mathrm{W}$ minerals induce lower bio- availability, thus resulting in a relatively higher concentration of unaltered $\mathrm{W}$ minerals in the soils.

\section{Discussion and conclusions}

The use of bioindicator species, determined by biogeochemical indices, aiming the detection of metals and metalloids in natural outcrops or in mineralized soils is feasible for mineral prospecting on this study area or other similar areas. Therefore, we conclude that the species and organs best suited for biogeochemical prospecting, and/or with potential for mine restoration, in the study area are by order of importance:

(i) As: old needles of $P$. pinaster, aerial tissues of $C$. vulgaris, C. tridentatum, leaves of C. ladanifer, E. umbellata and Q. ilex subsp. ballota.

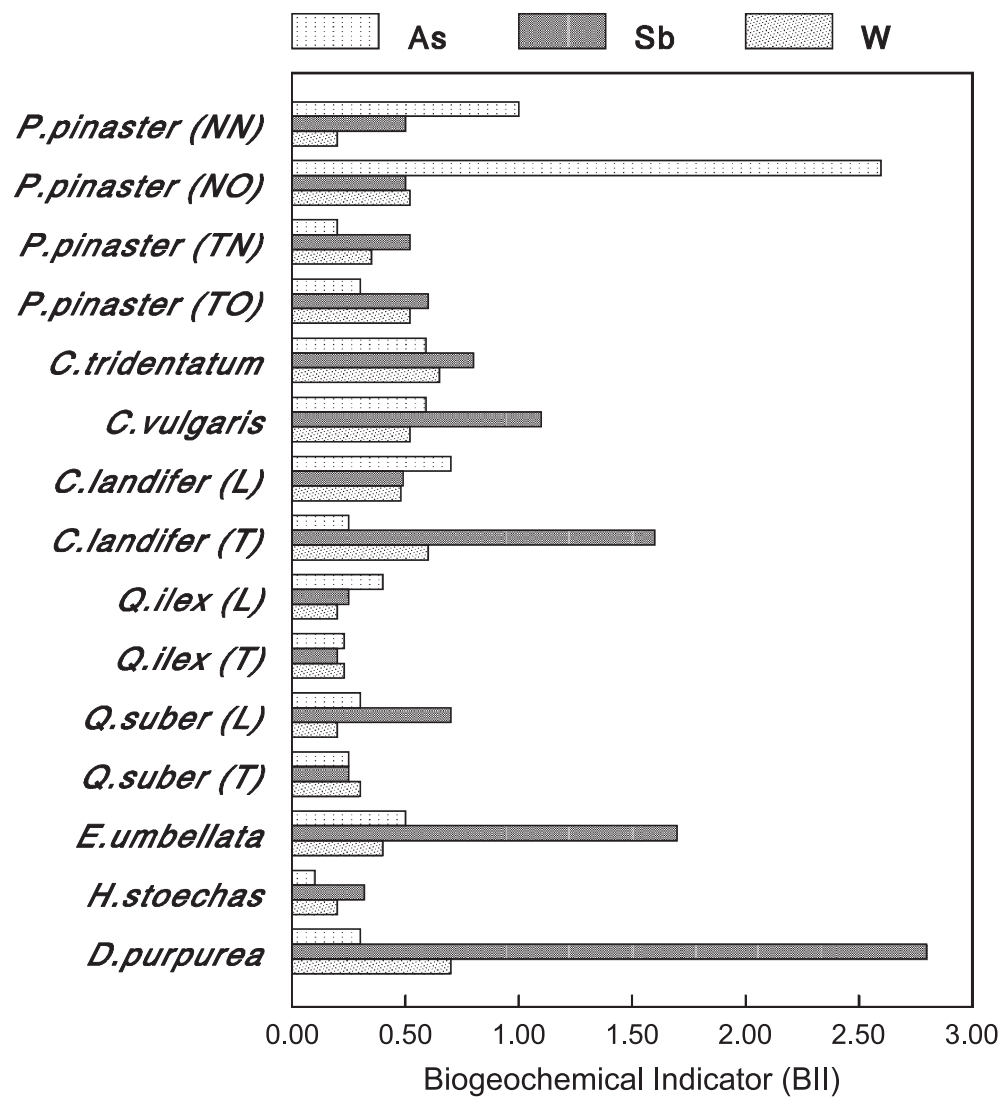

Fig. 3. Graphic representation of biogeochemical indicator index (BII). NN—new needles; NO—old needles; TN—new twigs; TO —old twigs; L-leaves; T=twigs. 
(ii) Sb: D. purpurea, E. umbellata, stems of $C$. ladanifer, C. vulgaris, C. tridentatum and stems of $P$. pinaster.

(iii) W: D. purpurea, C. tridentatum, old stems and old needles of $P$. pinaster, stem and leaves of $C$. ladanifer, E. umbellata and stems and leaves of Q. ilex.

To establish the plant cover on the surface-mined sites, the two most important factors influencing species selection are the soil properties and the tolerance levels of the selected plants. Three categories of plants have been noted to possess the reclamation potential for mine areas. They are grasses, forbs and trees. Grasses (Poaceae) produce large amounts of biomass and are adapted to initiate regrowth rapidly (Table 2). Grasses have fibrous root systems, which hold soil in place, thereby controlling erosion.

Forbs - herbaceous flowering plants - are generally used in mine revegetation in conjunction with grasses. Forbs usually have broad leaves, flowers and a branching taproot system. Forbs can be further classified as legumes and nonlegumes. Legumes are especially important for revegetating mined lands because they are capable of using nitrogen $(\mathrm{N})$ from the air to meet their $\mathrm{N}$ nutrition requirements, and they can transfer this "fixed" $\mathrm{N}$ to other components of the plant/soil system. Nonleguminous Forbs are also broad-leaved plants with showy flowers. The establishment of trees and shrubs on mined lands is the final stage of reclamation (Berry, 1995; Bending and Moffat, 1999).

The identified assemblage of plants (see Table 2) consists of the above three categories, and they are well adapted to the metal toxicity (Pulford and Watson, 2003). Phytostabilization of mining sites is a well-established environmental compliance using plant species that adapt different strategies such as metal tolerance, metal accumulation and metal exclusion (Dahmani-Muller et al., 2000; Shu et al., 2000; Tang et al., 1999, 2001; Yang et al., 1997; Zhang et al., 2001; Wong, 2003). This type of approach requires more and more information about plant communities growing on different kind of abandoned mine sites to assess their potential for phytostabilization of abandoned mines.

The physicochemical properties of the metalcontaminated soils tend to inhibit soil-forming pro- cesses and plant growth. In addition to elevated metal concentrations, other adverse factors included absence of topsoil, periodic sheet erosion, drought, surface mobility, compaction, wide temperature fluctuations, absence of soil-forming fine materials and shortage of essential nutrients (Wong et al., 1999a,b). The minedegraded soils usually have low concentrations of important nutrients, like K, P and N (Huenneke et al., 1990). Toxic metals can also adversely affect the number, diversity and activity of soil organisms, inhibiting soil organic matter decomposition and $\mathrm{N}$ mineralization processes. The chemical form of the potential toxic metal, the presence of other chemicals which may aggravate or ameliorate metal toxicity, the prevailing $\mathrm{pH}$ and the poor nutrient status of contaminated soil will affect the way plants respond to the toxic metal. Substrate $\mathrm{pH}$ affects plant growth mainly through its effect on the solubility of chemicals, including toxic metals and nutrients. According to Adriano (2001), three important factors that may affect the bioavailability of metals are the following: (i) soil capacity: $\mathrm{pH}$, cation exchange capacity, organic matter, amount and type of clay, ion interactions, oxides of $\mathrm{Fe}$ and $\mathrm{Mn}$ and redox potential; (ii) plant capacity such as species, cultivar, age of plant part; and (iii) plant metal interaction.

Phytoremediation of heavy-metal-contaminated soils basically includes phytostabilization and phytoextraction. Some soils are so heavily contaminated that removal of metals using plants would take an unrealistic amount of time. The normal practice is to choose drought-resistant fast-growing crops or fodder which can grow in metal-contaminated and nutrientdeficient soils.

Therefore, if the target is to partly remove the bioavailable toxic elements, then, based on the aforementioned results, the plant species to be used for the purpose of mine restoration and minimization of mining impacts are the following: $P$. pinaster for arsenic and tungsten, C.ladanifer and $C$. vulgaris for antimony and tungsten; $D$. purpurea and E. umbellata for antimony; and Q. ilex, C. tridentatum and $E$. globulus for tungsten. However, if the objective is to select metal tolerant nonaccumulator plant species in places like landfills where retention is the key issue and it is important to minimize the output of the toxic elements to the ecosystem, then the plant species to be selected are the following: E. globulus and $H$. 
stoechas for arsenic; Agrostis curtisii for antimony; Genista triacanthos, Rubus ulmifolius and Agrostis delicatula for arsenic and antimony; and Halimium ocymoides and Lavandula stoechas subsp. stoechas for arsenic, antimony and tungsten.

\section{References}

Adriano, D.C., 2001. Trace Elements in Terrestrial Environments: Biogeochemistry Bioavailability and Risks of Metals, 2nd ed. Springer-Verlag, New York, p. 866.

Badri, M., Springuel, I., 1994. Biogeochemical prospecting in the south-eastern desert of Egypt. J. Arid Environ. 28, 257-264.

Baker, A.J.M., 1981. Accumulators and excluders: strategies in the response of plants to trace metals. J. Plant Nutr. 3, 643-654.

Baker, A.J.M., McGrath, S.P., Sidoli, C.M.D., Reeves, R.D., 1994. The possibility of in situ heavy metal decontamination of polluted soils using crops of metal accumulating plants. Resour. Conserv., 1141-1149.

Bending, N.A.D., Moffat, A.J., 1999. Tree performance on mine spoils in the South Wales coalfield. J. Appl. Ecol. 36, $784-797$.

Berry, C.R., 1995. Growth and heavy metal accumulation in pine seedlings grown with sewage sludge. J. Environ. Qual. 14, 415-419.

Bradshaw, A.D., 1993. Understanding the fundamentals of succession. In: Miles, J., Walton, D.H. (Eds.), Primary Succession on Land. Blackwell Oxford.

Brooks, R.R., 1983. Biological Methods of Prospecting for Minerals. Wiley-Interscience, New York, p. 313.

Centro de Valorizacao de Recursos Minerais, 1988. Sistema ANDAD-Manual do utilizador Centro de Valorização de Recursos Minerais. I.S.T., Lisboa, p. 43.

Dahmani-Muller, H., van Oort, F., Gélie, B., Balabane, M., 2000. Strategies of heavy metal uptake by three plant species growing near a metal smelter. Environ. Pollut. 109, 231-238.

Fletcher, W.K., 1981. Analytical methods in geochemical prospecting. In: Govett, G.J.S. (Ed.), Handbook of Exploration Geochemistry, vol. 1. Elsevier, p. 255.

Franco, J.A., 1971. Nova Flora de Portugal Continente e Açores Vol. I. Lycopodiaceae-Umbelliferae. Escolar Editora, Lisboa, p. 555 .

Franco, J.A., 1984. Nova Flora de Portugal Continente e Açores Vol. II Lycopodiaceae-Umbelliferae. Escolar Editora, Lisboa, p. 659 .

Freitas, H., Prasad, M.N.V., Pratas, J., 2004a. Analysis of serpentinophytes from north-east of Portugal for trace metal accumulation-relevance to the management of mine environment. Chemosphere 54, 1625-1642.

Freitas, H., Prasad, M.N.V., Pratas, J., 2004b. Plant community tolerant to trace elements growing on the degraded soils of São Domingos mine in the south east of Portugal: environmental implications. Environ. Int. 30, 65-72.
Hooper, D.U., Vitousek, P.M., 1997. The effects of plant composition and diversity on ecosystem processes. Science 277, $1302-1305$.

Huenneke, L.F., Hamburg, S.P., Koide, R., Mooney, H.A., Vitousek, P.M., 1990. Effects of soil resources on plant invasion and community structure in Californian serpentine grassland. Eco$\operatorname{logy} 71(2), 478-491$.

Kabata-Pendias, A., 2001. Trace Elements in Soil and Plants. CRC Press, Florida, p. 432.

Kovalevskii, A.L., 1979. Biogeochemical Exploration for Mineral Deposits. Oxonian Press Pvt., New Delhi, p. 136.

Levinson, A., 1974. An Introduction to Exploration Geochemistry. Applied Publishing, Calgary, p. 612.

McInnes, B.I.A., Dunn, C., Cameron, E.M., Kameko, L., 1996. Biogeochemical exploration for gold in tropical rain forest regions of Papua New Guinea. J. Geochem. Explor. 57, 227-243.

Pereira, H.G., Renca, S., Saraiva, J., 2003. A case study on geochemical identification through principal component analysis supplementary projection. Appl. Geochem. 18, 37-44.

Pratas, J.A.M.S., 1996. Aplicacoes de Prospeccao Biogeoquimica. Seleccao de especies bioindicadoras em algumas areas mineiras de Portugal. Applications of biogeochemical prospecting: selection of bio-indicator plant species in some mining areas of Portugal (in Portuguese). PhD Thesis, (vol. 3). Universidade de Coimbra, p. 1027.

Pratas, J., Prasad, M.N.V., Freitas, H., Conde, L., 2004. Pinus pinaster Aiton maritime pine: a reliable indicator for delineating areas of anomalous soil composition for biogeochemical prospecting of As (Arsenic) Sb (Antimony) and W (Tungsten). Eur. J. Miner. Process. Environ. Protect. 4 (in press).

Pulford, I.D., Watson, C., 2003. Phytoremediation of heavy metal-contaminated land by trees-a review. Environ. Int. 29, 529-540.

Quin, B.F., Brooks, R.R., 1972. The rapid determination of tungsten in soils rocks and vegetation. Anal. Chim. Acta 58, 301-309.

Shu, W.S., Lan, C.Y., Zhang, Z.Q., Wong, M.H., 2000. Use of vetiver and other three grasses for revegetation of $\mathrm{Pb} / \mathrm{Zn}$ mine tailings at Lechang Guangdong province: field experiment. 2nd Int. Vetiver Conf. Bangkok Thailand.

Singh, A., Singh, A.K., Flatman, G., 1994. Estimation of background levels of contaminants. Math. Geol. 26, 361-388.

Tang, S., Wilke, B.M., Huang, C., 1999. The uptake of copper by plants dominantly growing on copper mining spoils along the Yangtze River the People's Republic of China. Plant Soil 209, $225-232$.

Tang, S., Wilko, B.M., Brooks, R.R., 2001. Heavy metal uptake by metal-tolerant Elsholtzia haichowensis and Commelina communis from China. Commun. Soil Sci. Plant Anal. 32, $895-906$.

Van Loon, J.C., 1985. Selected Methods of Trace Metal Analysis: Biological and Environmental Samples. John Willey \& Sons, p. 355 .

Vijan, P.N., Rayner, A.C., Sturgis, D., Wood, G.R., 1976. A semiautomated method for the determination of arsenic in soil and vegetation by gas-phase sampling and atomic absorption spectrometry. Anal. Chim. Acta 82, 329-336. 
Wong, M.H., 2003. Ecological restoration of mine degraded soils with emphasis on metal contaminated soils. Chemosphere 50, $775-780$.

Wong, J.W.C., Chen, Q., Zhang, F.S., Wong, M.H., Baker, A.J.M., 1999a. Phytostabilization of mimicked cadmium contaminated soil with lime amendment. Proc. 5th Int. Conf. Biogeochem. Trace Elements. Vienna.

Wong, M.H., Lan, C.Y., Gao, L., Chen, H.M., 1999b. Current approaches to managing and remediating metal contaminated soils in China. Proc. 5th Int. Conf. Biogeochem. Trace Elements. Vienna, Austria.

Yang, Z.Y., Yuan, J.G., Xin, G.R., Chang, H.T., Wong, M.H., 1997. Germination growth and nodulation of Sesbania rostrata grown in $\mathrm{Pb} / \mathrm{Zn}$ mine tailings. Environ. Manage. $21,617-622$.

Zhang, Z.Q., Shu, W.S., Lan, C.Y., Wong, M.H., 2001. Soil seed bank as an input of seed source in revegetation of lead/zinc mine tailings. Restor. Ecol. 9, 1-8. 